\title{
Postproduction Carbohydrate Levels in Pot Chrysanthemums
}

\author{
Susan E. Trusty'and William B. Miller \\ Department of Plant Sciences, University of Arizona, Tucson, AZ 85721 \\ Additional index words. Chrysanthemum morifolium, Dendranthema $\times$ grandiflorum, fructan, greenhouse crop \\ physiology, senescence
}

\begin{abstract}
-Abstract. Postproduction changes in carbohydrate types and quantities in the leaves, stems, and inflorescences of pot chyrsanthemums [Dendranthema $\times$ gramfiflorum (Ramat.) Kitamura 'Favor'] placed in interior conditions were investigated. Fructans, sucrose, glucose, and fructose were present in all plant parts. In inflorescences and leaves, an additional unidentified substance was present. All plant parts decreased in dry weight during the postproduction evaluation. This decrease was accompanied by overall reductions in total soluble carbohydrates (TSC) and starch. The appearance of leaves and stems was acceptable throughout the experiment. Leaves lost significant amounts of TSC during the first 4 days postproduction (DPP), due primarily to a $76 \%$ decrease in sucrose concentration. After 4 DPP, leaf and stem TSC remained relatively unchanged. In inflorescences, petal expansion continued through 12 DPP. Visible signs of senescence, including loss of turgor, color changes, and inrolling of petal edges were observed at $20 \mathrm{DPP}$, and by $28 \mathrm{DPP}$, the plants were determined unacceptable for consumer use. Inflorescences increased in fresh weight, but not dry weight, during petal expansion, then each decreased. Inflorescence TSC fell from $146 \mathrm{mg.g}{ }^{1}$ dry weight at O DPP to $11 \mathrm{mg} . \mathrm{g}^{-1}$ at 28 DPP. Reducing sugars accounted for $84 \%$ of the inflorescence TSC at 4 DPP, dropping to $48 \%$ at 28 DPP. Fructan concentration decreased through 16 DPP and then remained unchanged, while starch levels rose from 25 to $34 \mathrm{mg} \cdot{ }^{-1}$ dry weight through $12 \mathrm{DPP}$, then decreased. Fractans decreased in polymerization during petal expansion. This result suggests an alternate use of fructans and starch as pools of available reserve carbohydrate during petal expansion in chrysanthemum.
\end{abstract}

Many studies have dealt with factors that influence the longevity of cut flowers (Halevy and Mayak, 1979), whereas little information is available regarding longevity of flowering pot plants. Preharvest factors, such as nutrient status, and cultivar selection have been shown to affect plant longevity in potted poinsettia (Scott et al., 1982) and chrysanthemum (Nell, 1989). Easter lilies grown under suboptimal irradiances have low leaf and flower bud carbohydrate levels and their flower longevity may be affected (Miller and Langhans, 1989). In chrysanthemum, Nell et al. (1990) found that postproduction longevity is reduced when low irradiance levels are used during production. These results suggest that carbohydrate levels may play a role in the longevity of potted chrysanthemums.

With cut flowers, an important aspect of increasing longevity is maintenance of the carbohydrate pool and active osmotica in floral tissues (Mayak and Halevy, 1980). This phenomenon is demonstrated by the delay in senescence achieved by adding sugar to cut-flower vase solutions. A detailed investigation of the carbohydrate metabolism of whole chrysanthemum plants has not yet been made. The objectives of this study were to characterize the relationship between carbohydrate levels and flower senescence in chrysanthemum in florescences and describe the changes in carbohydrate pool sizes in whole plants during senescence.

Received for publication 19 Dec. 1990. We gratefully acknowledge the Fred C. Gloeckner Foundation for HPLC equipment and Yoder Brothers for providing rooted cuttings. We also thank Larry Kasperson for plant care, Della Carbonaro for excellent technical assistance, and Terry Reindl for drawing Fig. 1. The cost of publishing this paper was defrayed in part by the payment of page charges. Under postal regulations, this paper therefore must be hereby marked advertisement solely to indicate this fact.

Graduate Assistant.

${ }^{2}$ Assistant Professor of Plant Sciences, to whom reprint requests should be addressed. Current address: Dept. of Horticulture, Clemson Univ., Clemson, SC 29634.

\section{Materials and Methods}

Plant culture. Rooted cuttings of 'Favor' chrysanthemum were planted three per 12.5 -cm-diameter (1.2-liter) plastic container with 1 soil : 2 sphagnum peat : 2 perlite (by volume) medium amended (per cubic meter) with $890 \mathrm{~g}$ treble superphosphate, $593 \mathrm{~g}$ potassium nitrate, $593 \mathrm{~g}$ magnesium sulfate, $4.75 \mathrm{~kg}$ ground dolomitic limestone, and $74 \mathrm{~g}$ Frit Industries Trace Elements no. 555 (Peters Fertilizer Products, W.R. Grace \& Co., Fogelsville, Pa). One pot was considered a commercial unit or "plant." Plants were grown in a polyethylene-covered, fan- and pad-cooled greenhouse with $24 \mathrm{C}$ days and $15 \mathrm{C}$ nights.

Plantings were made on 21 Dec. (Expt. 1) and 9 Jan. (Expt. 2). Plants received $4 \mathrm{~h}$ of noninductive night interruptions (2200 to $0200 \mathrm{HR}$ ) with incandescent lamps. Plants were pinched 21 days after planting to remove the apex and associated young leaves and then were subjected to natural short days. About 3 weeks after pinching, individual plants were pruned to four uniform shoots (12 shoots/pot, total). Lateral flower buds were removed as they became accessible. The plants were fertilized with $300 \mathrm{mg} \mathrm{N}$ and K/liter (supplied from $780 \mathrm{mg}$ potassium nitrate and $550 \mathrm{mg}$ ammonium nitrate/liter) at each watering. The fertilizer solution was maintained at $\mathrm{pH} 6.0$ with $75 \%$ (w/w) technical-grade phosphoric acid, which supplied $37 \mathrm{mg}$ P/liter at each watering. Butanedioic acid mono(2,2-dimethy 1 hydrazide) (daminozide) was applied at $2500 \mathrm{mg}$.liter ${ }^{-1}$ to runoff as a foliar spray 14 days after the pinch.

Plants with uniform height, flower count, and flower maturity were moved to the postproduction room when petals elongated and showed color and the outer rows of florets on most flowers were within $\approx 30 \%$ of perpendicular to the stem. Interior lighting (12 h.day 1 , was from $115-\mathrm{W}$ cool-white fluorescent lamps suspended above the plants. Photosynthetic photon flux at the top of inflorescences averaged $20 \pm 6 \mu \mathrm{mol} . \mathrm{m}^{-2} \cdot \mathrm{s}^{-1} \mathrm{during}$ illumination. The room was maintained at $21 \pm 2 \mathrm{C}$. At this

Abbreviations: DP, degree of polymerization DPP, days postproduction MCW, methanol : chloroform : water; TSC, total soluble carbohydrate. 

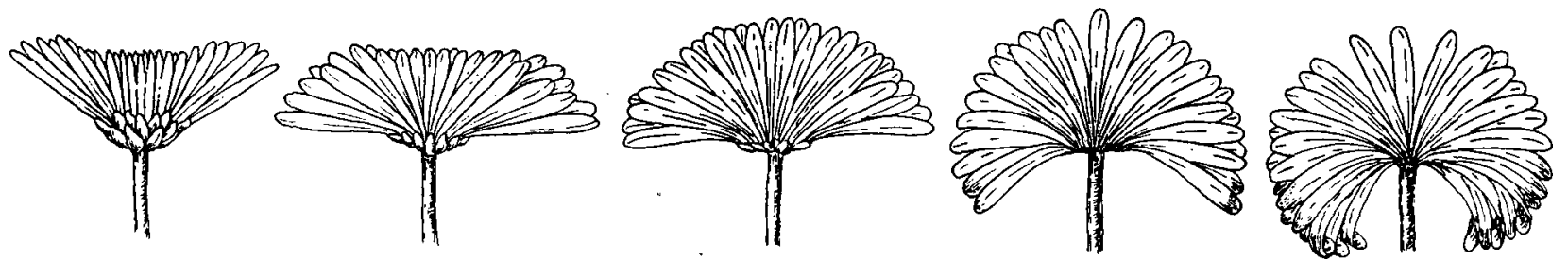

Fig. 1. Stages in flower development. (left to right) $\mathrm{O}=$ harvest, 8 to 10 rows of ray florets open; $1=$ florets perpendicular to the stem, some undeveloped ray florets; 2 = ray florets fully developed; 3 = florets relaxed beyond perpendicular, center disk florets visible on many flowers; 4 = completely relaxed inflorescence, center open, more than five rows of florets have lost turgidity.
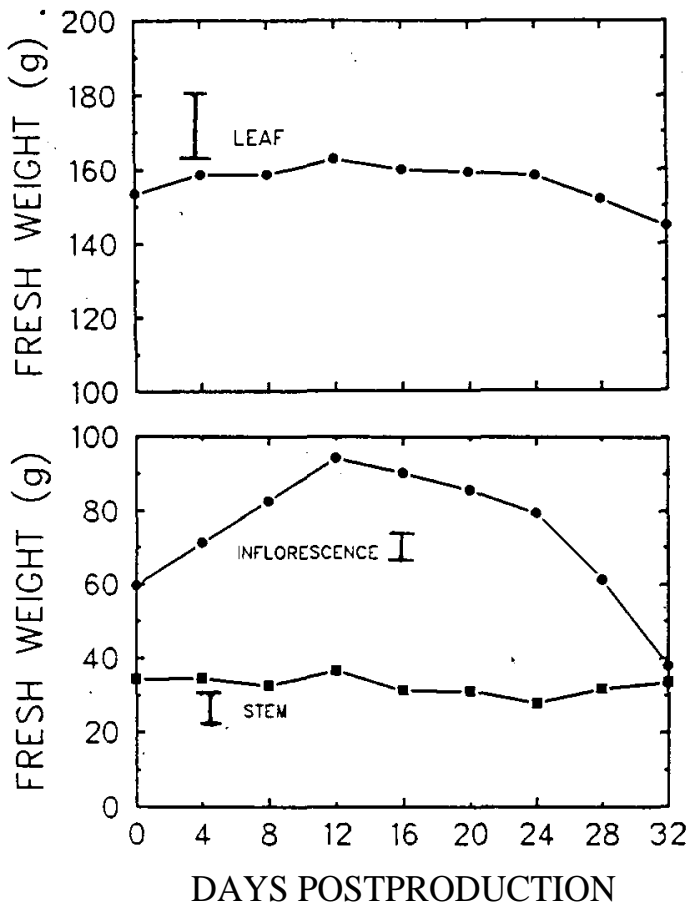

Fig.2. Fresh weight of inflorescence, leaves, and stems during the 32-day postproduction evaluation. Data represent the means of seven replications. Bars indicate the5\% LSD for each tissue type. The end of petal expansion and start, of unacceptable plant appearance occurred at 12 and 28 DPP, respectively.

time and every 4th day (at $1200 \mathrm{HR}$ ), flowers, leaves, and above-ground stems from seven plants were harvested and fresh weights determined. The inflorescences were severed at the base of the calyx and were not dissected further. All tissues were immediately frozen in liquid nitrogen and stored at $-70 \mathrm{C}$. The samples were freeze-dried, weighed, and then ground in a Wiley mill to pass through a 20-mesh screen. All freeze-dried samples were stored desiccated until extractions were made.

Carbohydrate extraction and analysis. Freeze-dried tissue (50 $\mathrm{mg}$ ) was loaded into disposable Pasteur pipets fitted with glass wool plugs and extracted with 12 methanol : 5 chloroform : 3 water (by volume, MCW) as described by Miller and Langhans (1989). Preliminary experiments indicated that mannitol was not present in chrysanthemum flowers, stems, or leaves in amounts detectable by high-performance liquid chromatography (HPLC); therefore, mannitol $(1.0 \mathrm{mg})$ was used as an internal standard and added during the first MCW extraction.

Fructan identification and separation. An oligosaccharide coeluting with Dahlia inulin (Sigma, St. Louis) and several associated early eluting oligosaccharides were postively identified as fructan by acid hydrolysis. The aqueous phase of plant MCW extracts was adjusted to $0.1 \mathrm{~N} \mathrm{H}_{2} \mathrm{~S} \mathrm{O}_{\mathrm{d}}$ and the solution placed
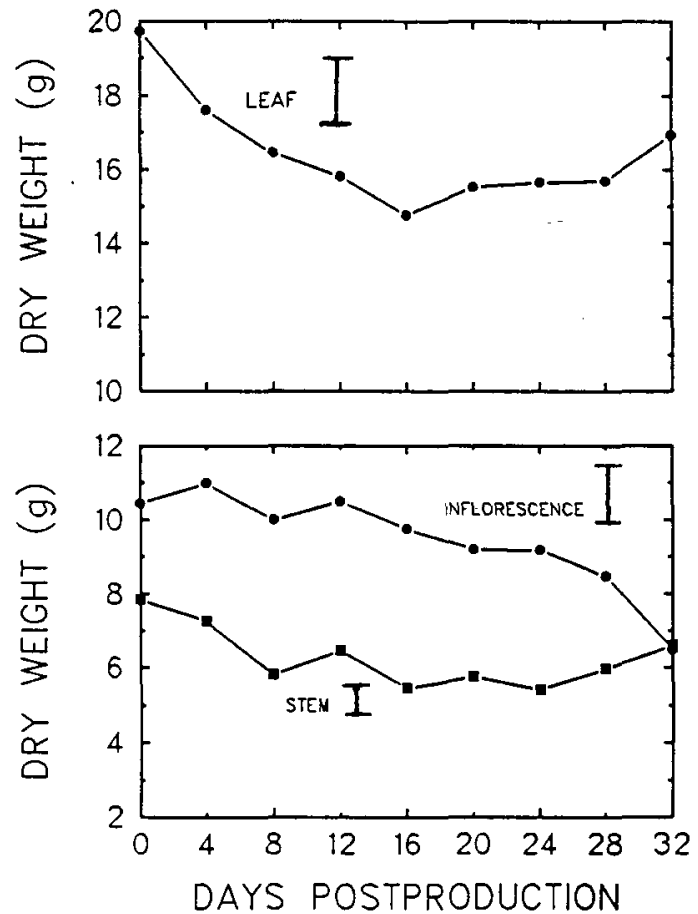

Fig. 3. Dry weight of inflorescences, leaves, and stems during the 32-day postproduction evaluation. Data represent the means of seven replications. Bars indicate the 5\% LSD for each tissue type. The end of petal expansion and start of unacceptable plant appearance occurred at 12 and $28 \mathrm{DPP}$, respectively.

in a boiling water bath for $20 \mathrm{~min}$. Samples were cooled and neutralized to $\mathrm{pH} 7$ with $1.0 \mathrm{~N} \mathrm{NaOH}$. The liquid was applied to anion- and cation-exchange columns, concentrated, and injected into the HPLC as described above. The absence of the early eluting (fructan) peaks with a corresponding large increase in fructose and a smaller increase in glucose relative to unhydrolyzed samples confirmed that the oligosaccharides were fruc$\tan$.

To study changes in fructan polymer length, gel filtration experiments were conducted. From HPLC chromatograms, calculations were made to determine the quantity of tissue needed to extract $=1 \mathrm{mg}$ of fructan from each sample. Fructan polymers were isolated from developing inflorescence tissues from $\mathrm{O}, 4$, 8 , and 12 DPP. The tissues were extracted three times each with $2 \mathrm{ml} 85 \%$ EtOH. The tissue residue was then extracted three times each with $2 \mathrm{ml}$ of glass-distilled water. The alcohol and water extracts were combined, passed over anion and cation columns, evaporated to dryness, and then dissolved in $2.5 \mathrm{ml}$ of HPLC water. The samples were passed through a $0.45-\mu \mathrm{m}$ membrane filter and applied to a $1.5 \times 110-\mathrm{cm}$ column of BioGel P4, 200-400 mesh (Bio-Rad Laboratories, Richmond, Calif.), with glass-distilled water as the eluant. Fractions of $2.8 \mathrm{ml}$ were 
Table 1. Change in appearance during senescence of 'Favor' chrysanthemum plants, based on a rating scale from $\mathrm{O}$ (excellent) through 4 (unacceptable).

\begin{tabular}{|c|c|c|c|c|c|c|c|}
\hline \multirow{2}{*}{$\begin{array}{c}\text { Days in } \\
\text { PostProduction } \\
\text { environment }\end{array}$} & \multicolumn{3}{|c|}{ Inflorescence } & \multicolumn{2}{|c|}{ Foliage } & \multirow{2}{*}{$\frac{\text { Stem }}{\text { Condition }}$} & \multirow{2}{*}{$\begin{array}{c}\text { Overall } \\
\text { plant } \\
\text { appearance }\end{array}$} \\
\hline & Openness & Color & Condition & Color & Condition & & \\
\hline o & 0.1 & 0.1 & 0.0 & 0.0 & 0.0 & 0.0 & 0.0 \\
\hline 4 & 0.9 & 0.8 & 0.0 & 0.0 & 0.0 & 0.0 & 0.0 \\
\hline 8 & 1.0 & 1.0 & 0.7 & 0.0 & 0.0 & 0.0 & 0.7 \\
\hline 12 & 2.0 & 1.0 & 1.1 & 0.0 & 0.0 & 0.0 & 1.1 \\
\hline 16 & 2.1 & 1.7 & 1.2 & 0.0 & 0.7 & 0.0 & 2.0 \\
\hline 20 & 2.4 & 2.8 & 2.0 & 1.7 & 2.0 & 0.1 & 2.9 \\
\hline 24 & 2.9 & 3.0 & 2.4 & 2.0 & 2.1 & 0.9 & 3.1 \\
\hline 28 & 4.0 & 3.4 & 3.6 & 2.6 & 2.1 & 1.0 & 4.0 \\
\hline 32 & 4.0 & 4.0 & 4.0 & 3.3 & 3.0 & 2.0 & 4.0 \\
\hline $\begin{array}{c}\text { Significance } \\
\text { Linear }\end{array}$ & $* * *$ & $* * *$ & $* * *$ & $* * *$ & $* * *$ & $* * *$ & $* * *$ \\
\hline Quadratic & & NS & NS & $*$ & NS & 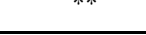 & NS \\
\hline
\end{tabular}

'Data are the average of 14 plants per observation period.

Ns, ${ }^{*} * *, * * *$ Linear or quadratic models are nonsignificant or significant at $P=0.05,0.01$, or 0.001 , respectively.

collected over $8 \mathrm{~h}$ at a rate of $0.48 \mathrm{ml} \cdot \mathrm{min}^{-1}$. Fractions were hydrolyzed as described above, then analyzed for reducing sugar content.

Plant appearance and longevity. In each experiment, 14 plants were observed in the postproduction room and rated for senescence characteristics based on a scale from $\mathrm{O}$ (no sign of aging or senescence) through 4 (aesthetically unacceptable). The stages of flower and foliage aging were categorized according to Fig. 1 and the following criteria. Flower color and condition: $\mathrm{O}=$ bright, clear bronze-red color, florets firm and fully turgid; 1 = coppery-bronze color, florets turgid, inflorescence loosening; 2 = slight "pinking" of the bronze florets, fewer than three rows of yellow florets in the center of inflorescence, florets slightly dull with slight rolling of outer petal edges; $3=$ more than three rows of yellow florets in center, outer rows of florets losing turgidity, rolling more pronounced; $4=$ florets fading to a muddy pink, more than five rows of florets have lost turgidity. Foliage color and condition: $\mathrm{O}=$ dark-green, healthy turgid foliage; 1 = slightly lighter green, leaves turgid but appear dull; $2=$ chlorosis at tips of inner and youngest leaves directly beneath flower head, less turgid; $3=$ estimate $10 \%$ of leaves with some chlorosis; $4=$ more than $10 \%$ of leaves exhibiting chlorosis, limp foliage. Stem condition: $\mathrm{O}=$ healthy, green, turgid stems; $1=$ purpling of stem just beneath flower head; 2 = purpling and some shrinking of stem beneath flower head. Overall appearance: $\mathrm{O}=$ ideal plant for retail market sales; 1 = nearing end of marketable stage; $2=$ desirable plant for home or office; $3=$ plant appearance is less than ideal; 4 = plant is no longer aesthetically acceptable.

We used a completely randomized design for the experiments. Appropriate data analyses were conducted using CoStat (CoHort Software, Berkeley, Calif.). The results from both experiments were similar. Results from the first experiment are presented.

\section{Results and Discussion}

Changes in fresh and dry weight. During postproduction, inflorescence fresh weight increased during petal expansion (until 12 to 16 DPP), then decreased, especially during the last 8 days (Fig. 2). Leaves and stems did not change significantly in fresh weight over the course of the experiment. All plant parts decreased in dry weight during the postproduction evaluation.
Most of the leaf and stem dry weight was lost in the first 12 to 16 DPP, whereas inflorescences lost the most dry weight in the last 8 days (Fig. 3). On a percentage basis, inflorescences lost the most dry weight, decreasing from $10.6 \mathrm{~g} / \mathrm{plant}$ to $6.5 \mathrm{~g}$ at 32 DPP, for a total loss of $39 \%$.

In the postproduction environment, petal expansion ( $\mathrm{O}$ to 12 DPP) was accompanied by increases in inflorescence fresh weight but not dry weight. Rutland and Seawright (1973) reported that in the greenhouse, chrysanthemum petal fresh weight increased linearly as petals expand from first petal coloration until pollen shed, while dry matter concentration decreased during the same 16 days. In cut flowers, reduced petal dry weight and carbohydrate level are attributed to limited substrate imported from leaves, as the leaf area is severely reduced with cutting (Rogers, 1973.) In pot plants, moving from presumably optimum greenhouse irradiances to lower irradiances would limit the amount of current assimilate exported from the leaves to the flowers since photosynthetic rate is severely reduced. Substantial amounts of dry weight are lost from the leaves and stems in the first 8 to 16 DPP, which may represent export of stem and leaf reserves to the inflorescence. Rapid petal respiration could account for the lack of dry weight increase in inflorescences in this period (Fig. 3).

Changes in appearance of flowers, leaves, and stems. The appearance of chrysanthemum plants declined significantly during the experiment (Table 1). Inflorescences displayed senescence characteristics earlier than leaves or stems. Visible signs of senescence, including loss of turgor, color changes, and inrolling of petal edges, were observed at 20 DPP. By 28 DPP, inflorescences were no longer acceptable for consumer use. Although leaves and stems showed a linear decline in appearance after 16 DPP, they were acceptable at the conclusion of the experiment. Overall plant appearance was judged unacceptable at $28 \mathrm{DPP}$, the time when inflorescences were determined to be unacceptable.

Carbohydrate composition of flowers, leaves, and stems. Several soluble sugars were present in all parts of flowering chrysanthemum plants, including (in order of HPLC elution) long-chain and several shorter chain oligosaccharides (classified as "fructan" after acid hydrolysis and monosaccharide analysis), sucrose, glucose, and fructose. In inflorescences and leaves, an additional unidentified substance eluting between glucose 

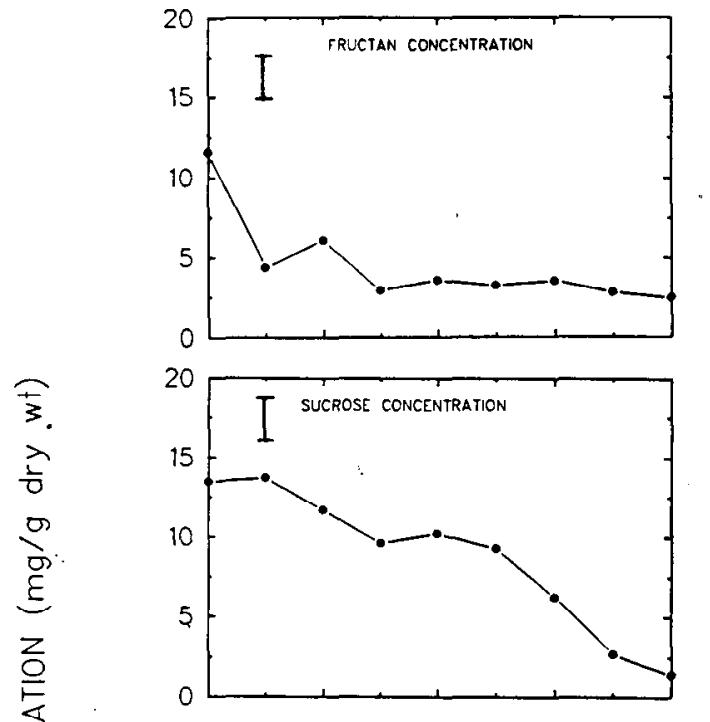

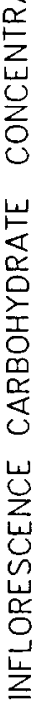
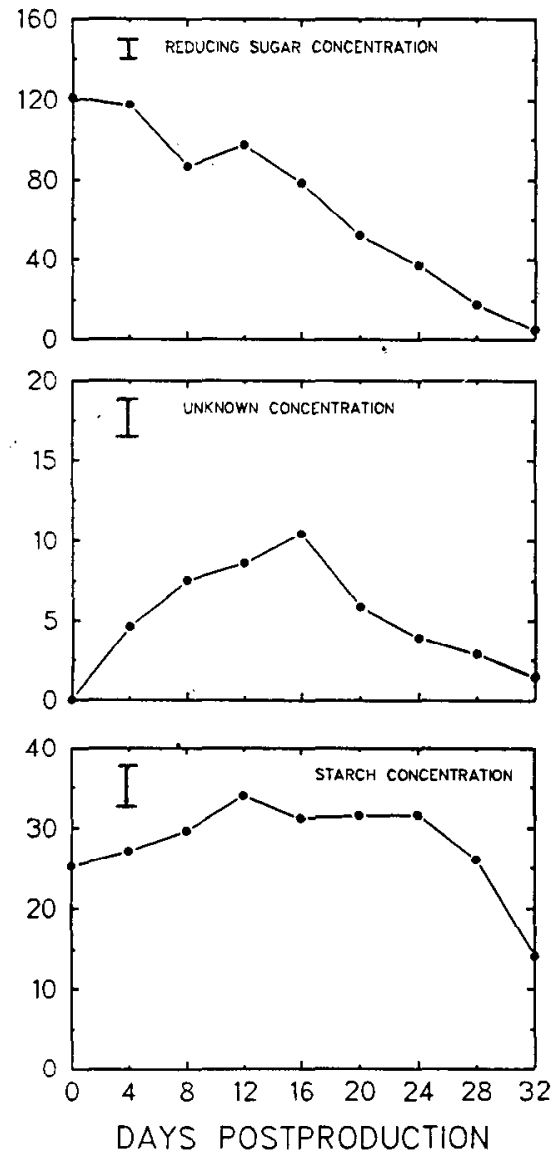

Fig. 4. Carbohydrate pool sizes ( $\mathrm{mg} \cdot \mathrm{g}^{-1} \mathrm{dry}$ weight) of inflorescences during the32-day postproduction period. Data represent the means of five replications. Bars indicate the 5\% LSD for each tissue type. The end of petal expansion and start of unacceptable plant appearance occurred at 12 and 28 DPP, respectively.

and fructose was present in varying amounts ( $2 \%$ to $20 \%$ of total soluble carbohydrate) and was not detected in stem tissues. The unknown did not co-elute with mannose, galactose, xylose, sorbitol, or any di-, tri-, oroligosaccharide.

Reducing sugars (Fig. 4) accounted for $\gg 84 \%$ of the soluble carbohydrates in the inflorescence in earlier stages of senescence and were responsible for the major change in inflorescence total
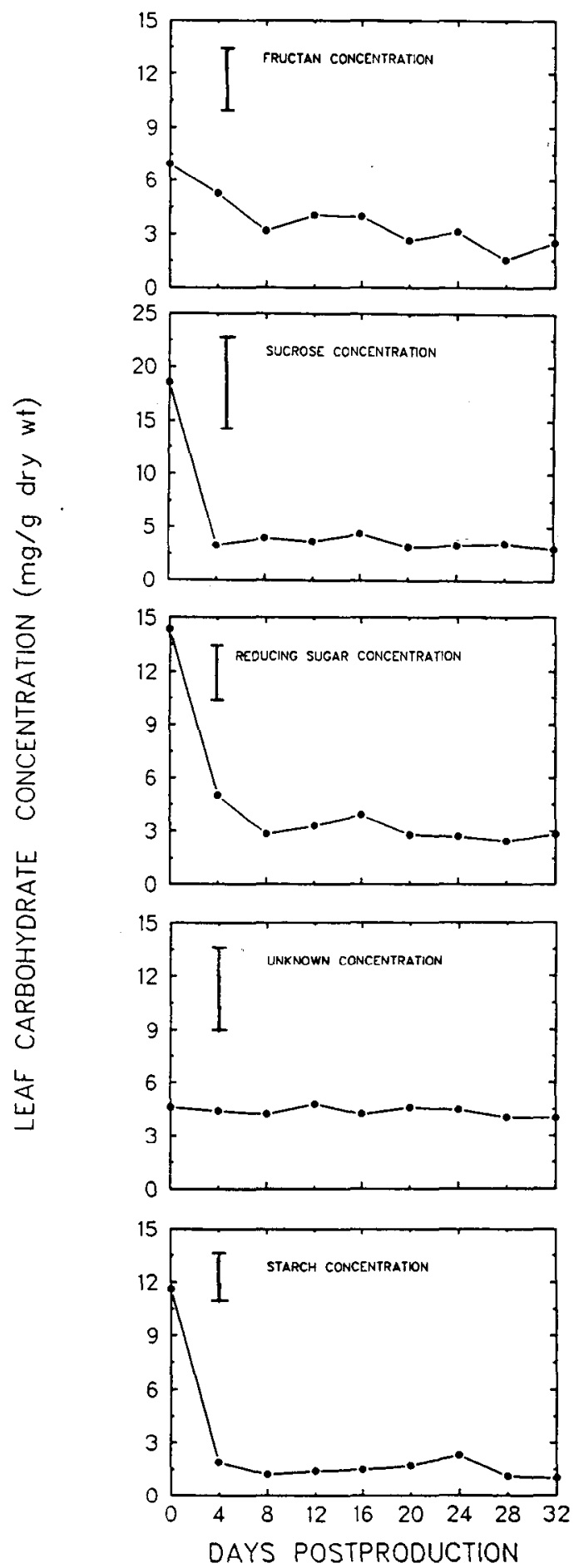

Fig.5. Carbohydrate pool sizes (mg.g-1 dry weight) of leaves during the 32-day postproduction period. Data represent the means of five replications. Bars indicate the5\% LSD for each tissue type. The end of petal expansion and start of unacceptable plant appearance occurred at 12 and 28 DPP, respectively.

soluble carbohydrate content overtime. On a concentration basis (mg-g-1 dry weight), inflorescences (Fig. 4) contained 8fold or more reducing sugar than found in leaves (Fig. 5). Sucrose was present in inflorescences in comparatively small amounts $(11 \% 0$ of the total) and its concentration decreased gradually during the postproduction period. Fructans decreased through 16 DPP and then remained unchanged (Fig. 4). Starch concentrations rose by $12 \mathrm{DPP}$, then decreased through $32 \mathrm{DPP}$. 


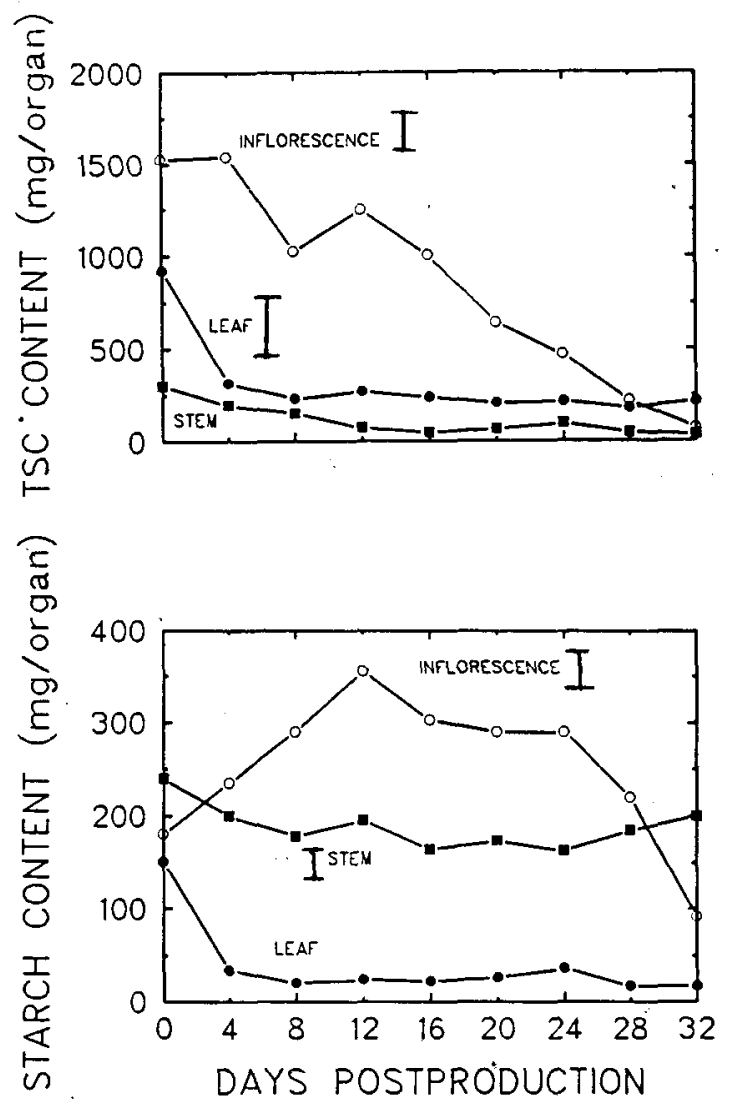

Fig. 6. Total soluble carbohydrate content and starch content per plant of inflorescences, leaves, and stems during the 32-day postproduction evaluation. Data represent the means of five replications. Vertical bars indicate the 5\% LSD; where not shown, the LSD falls within two symbol sizes. The end of petal expansion and start of unacceptable plant appearance occurred at 12 and 28 DPP, respectively.

In leaves, fructan, sucrose, reducing sugar, and starch concentrations all decreased between $\mathrm{O}$ and 4 to 8 DPP, then remained constant throughout the postproduction evaluation (Fig. 5). After 4 DPP, the TSC (sum of fructan, sucrose, reducing sugars, and the unidentified substance) pool in leaves was constant and consisted of about equal amounts of each component.

In stems, fructans initially comprised $50 \%$ of the $37.5 \mathrm{mg} \cdot \mathrm{g}^{-1}$ stem TSC, decreasing to $20 \%$ of stem TSC at 16 DPP. The reducing sugar content (nearly all fructose) increased in the first 8 DPP, then remained relatively unchanged. Sucrose concentration decreased slowly throughout the experiment. Final TSC concentration of stems was $5 \mathrm{mg} \cdot \mathrm{g}$-'dry weight.

On day $\mathrm{O}$, inflorescences accounted for $56 \%$ of the $2700 \mathrm{mg}$ TSC in the chrysanthemum plant and this increased to $75 \%$ at 4 DPP due to the initial drop in leaf TSC (Fig. 6). Inflorescences continued to be the major sites of plant soluble carbohydrate through 28 DPP.

Starch levels in inflorescences rose during petal expansion from $180 \mathrm{mg} / \mathrm{plant}$ to $350 \mathrm{mg}$ at $12 \mathrm{DPP}$ (Fig. 6). Levels then decreased to a final $110 \mathrm{mg} / \mathrm{plant}$, with most of the decrease occurring in the last two harvest periods after the onset of petal in-rolling and turgor loss at 20 DPP. Leaves lost $87 \%$ of the initial $160 \mathrm{mg}$ of starch in the first $4 \mathrm{DPP}$, then remained below $20 \mathrm{mg} / \mathrm{plant}$ for the duration of the experiment. Stem starch content decreased slightly in the first 8 DPP and did not change thereafter.

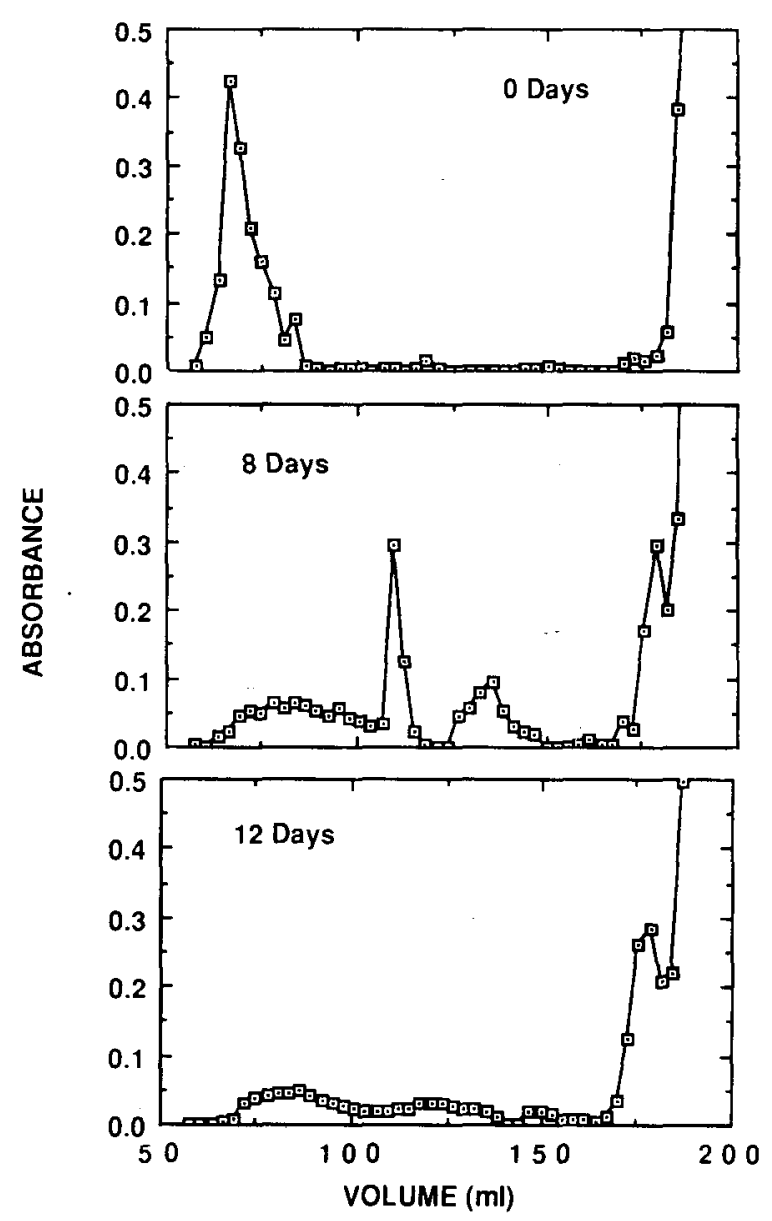

Fig. 7. Elution profile of fructans extracted from chrysanthemum inflorescences at 0,8 , and 12 DPP. Early peaks represent long-chain fructans. The large peak at $178 \mathrm{ml}$ includes mono- and disaccharides and possibly short-chain fructans (MW $<800$ ).

The carbohydrate profile in leaves was much different than in inflorescences. Leaf sucrose decreased by 7570 during the first $4 \mathrm{DPP}$, then remained constant. This is almost certainly due to reduced photosynthesis resulting from the decrease in irradiance as plants were moved from the greenhouse to the postharvest room. Total leaf carbohydrate levels, including soluble sugars and starch, remained constant throughout the remainder of the experiment even though visible leaf senescence began at 24 DPP. This indicates that leaf senescence was not related to the sugar concentration in leaves. Leaf senescence is often characterized by a loss of chlorophyll rather than a change in carbohydrates (Leopold, 1980). During the time that inflorescence appearance was acceptable, leaves and stems showed little sign of senescence. Total carbohydrate levels of leaves and stems did not decrease as flowers senesced; indeed, stem carbohydrate content was extremely low (Fig. 6). It appears that in the postproduction environment, inflorescerm.s were not a strong enough sink to draw additional carbohydrates from leaves that maintained a low, but increasingly larger, proportion of the total plant carbohydrate (Fig. 6).

Our data show that a substantial amount of free sugar remained in the inflorescences at the onset of wilting and senescence $\left(64 \mathrm{mg} \cdot \mathrm{g}^{-1}\right.$ dry weight at $\left.20 \mathrm{DPP}\right)$. Therefore, the final decline in in florescence appearance does not appear to be due to lack of respirable substrates. We did not conduct a study to determine more detailed carbohydrate localization within the 
organs of the inflorescence. Since most carbohydrates are present as glucose and fructose and these reducing sugars presumably cannot be translocated, the localization of carbohydrate supply vs. demand may be critical. Our findings support those of Tirosh and Mayak (1988), who found that substantial amounts of sugars are present in senescing carnation flowers.

Changes in fructan composition of inflorescence tissue. Imdin standards with a degree of polymerization (DP) of 30 to 35 fructose residues were applied to the Bio-Gel P4 column. Inulin eluted at $68 \mathrm{ml}$, while mono- and disaccharides eluted at 178 $\mathrm{ml}$. The first harvest (O DPP) occurred when inflorescences were partially expanded. At this relatively early stage in petal expansion, high DP fructans were present, as evidenced by early ehrtion volume of fructans (Fig. 7). At 8 DPP, high DP fructans were replaced by medium-chain polymers and some shorter polymers. These shorter polymers eluted just before the combined glucose, fructose, and sucrose peak that may also contain short-chain fructans with molecular weights of $<800$. By 12 DPP (end of petal expansion), virtually all long-chain polymers were hydrolyzed to shorter polymers.

During the time of fructan breakdown in chrysanthemum inflorescences ( $O$ to 16 DPP), starch levels in the flower steadily increased. Fructan levels did not significantly change after 16 days, whereas starch levels decreased. This pattern suggests an alternate use of starch and fructans as pools of available reserve carbohydrate. Fructans appeared to be broken down and used during growth and petal expansion, while starch was used during inflorescence senescence. A higher proportion of free fructose to glucose within the reducing sugar pool of flowers during petal expansion, which decreased with the onset of petal wilting, supports this idea.

Fructans are nonstructural carbohydrates generally found in leaves and underground storage tissues of grasses and selected dicots. Most fructans are distributed in plant tissues in a continuous series between $O$ DP and the member of the highest molecular weight isolated from the source (Edelman and Jefford, 1968). Fructans from members of the Composite family are of the inulin group, having $\beta-\left(2 \rightarrow 1^{\prime}\right)$-linked fructose residues with $\overline{\mathrm{D}} \overline{\mathrm{P}} \mathrm{s}$ up to $\overline{35}$, and have mostly " been investigated in leaves and underground storage organs (Edelman and Jefford, 1968; Nelson and Spollen, 1987; Pollock, 1986). We are unaware of any other reports of fructans being isolated and characterized from flower petal tissues.

Low-DP fructans occur in abundance in the growing regions of cool-season grass leaves, where cells are actively dividing and elongating (Volenec and Nelson, 1984), suggesting that fructans may play an osmotic role in tissues where water is entering growing cells and causing enlargement. Likewise, fructan depolymerization has been correlated with cell expansion in developing onion cells (Derbyshire and Henry, 1978). The breakdown to lower DP fructans during chrysanthemum inflorescence development suggests a possible role of fructans as an osmoticum, causing an influx of water to drive petal expansion.

\section{Literature Cited}

Derbyshire, B. and R.J. Henchy. 1978. The distribution of fructans in onions. New Phytol. 81:29-34.

Edelman, J. and T.G. Jefford. 1968. The mechanism of fructosan metabolism in higher plants as exemplified in Helianthus tuberosus. New Phytol. 67:517-531.

Halevy, A.H. and S. Mayak. 1979. Senescence and postharvest physiology of cut flowers. I. Hort. Rev. 1:204-236,.

Leopold, A.C. 1980. Aging and senescence in plant development, p. 2-12. In: K.V. Thimann (cd.). Senescence in plants. CRC Press, Boca Raton, Fla.

Mayak, S. and A. H. Halevy. 1980. Flower senescence, p. 131-156. In: K.V. Thimann (cd.). Senescence in plants. CRC Press, Boca Raton, Fla.

Miller, W.B. and R.W. Langhans. 1989. Carbohydrate changes of Easter lilies during growth in normal and reduced irradiance environments. J. Amer. Soc. Hort. Sci. 114:31\&315.

Nell, T.A. 1989. Postproduction longevity, p. 55-57. In: H.K. Tayama and T.J. Roll (eds.). Tips on growing potted chrysanthemums. Ohio Coop. Ext. Serv., The Ohio State Univ., Columbus.

Nell, T.A., R.T. Leonard, and J.E. Barrett. 1990. Production and postproduction irradiance affects acclimatization and longevity of potted chrysanthemum and poinsettia. J. Amer. Soc. Hort. Sci. 115:262-265.

Nelson, C.J. and W.G. Spollen. 1987. Fructans. Physiol Plant. 71:512516.

Pollock, C.J. 1986. Fructans and the metabolism of sucrose in vascular plants. New Phytol. 104:1-24.

Rogers, M.N. 1973. An historical and critical review of postharvest physiology research on cut flowers. HortScience 8:189-194.

Rutland, R.B. and K.W. Seawright. 1973. Anthocyanin in flowers of Chrysanthemum morifolium Ram. during anthesis in relation to sugar content. J. Amer. Soc. Hort. Sci. 98:74-77.

Scott, L. F., T.M. Blessington, and J.A. Price. 1982. Postharvest performance of poinsettia as affected by micronutrient source, storage, and cultivar. HortScience 17:901-902.

Tirosh, T. and S. Mayak. 1988. Changes in starch content during the development of carnation petals. J. Plant Physiol. 133:361-363.

Volenec, J.J. and C.J. Nelson. 1984. Carbohydrate metabolism in leaf meristems of tall fescue. Plant Physiol. 74:590-594. 